\title{
Environmental and Genetical Differences in Linear and Adiposity Dimen- sions Among Adolescents Boys
}

\author{
Rashmi Sinha ${ }^{1}$, Satwanti Kapoor ${ }^{*, 2}$, N.K. Mungreiphy ${ }^{1}$ and Anup Kumar Kapoor ${ }^{2}$ \\ ${ }^{I}$ Faculty of Anthropology, School of Social Sciences, Indira Gandhi National Open University, New Delhi 110068, India \\ ${ }^{2}$ Department of Anthropology, University of Delhi, Delhi 110007, India
}

\begin{abstract}
The present study comprises of cross sectional data on 414 Punjabi Khatri adolescent boys at a yearly interval from age 11 through 17 years. This group was compared with endogamous 140 Jat Sikhs, an agricultural land owning rural community, for profile of fatness. The anthropometric measurements taken on adolescent boys include weight, stature and skinfold thickness at biceps, triceps, suprailiac and medial calf. A gradual increase of weight from 11 to 16 years and a marginal increase from 16 to 17 years among the Punjabi Khatri boys is noticed, the same being true for stature also. The Jat Sikh boys increase gradually with peak increase in stature at 13-14 years of age followed by peak increase in weight at 14-15 years. Adolescent Punjabi khatri adolescents have more BMI than Jat Sikhs. Among the Punjabi khatri adolescent boys there is a fluctuation in fat content when calculated from GMT with maximum fat content at 12 years and in subsequent years it declines though pattern is inconsistent. As for Jat Sikh boys, maximum GMT is at 14 years and then fat decreases during the period. Biceps remains the site of minimum fat in all the age groups in both Punjabi khatri and Jat Sikh adolescent boys. The pattern is same in all the age groups in Punjabi khatri boys affirming the phenomenon of redistribution of fat away from extremity towards the trunk. As far as Jat Sikh adolescent boys are concerned there is an intersite shift at 17 years from suprailiac to medial calf deviating from the usual away from extremity towards the trunk. Suprailiac is the most sensitive site followed by medial calf in both adolescent Punjabi khatri and Jat Sikh boys.
\end{abstract}

Keywords: Adolescent boys, BMI, Spurt, Sensitivity, Environment.

\section{INTRODUCTION}

Growth is a biological phenomenon experienced by all living organisms. It is a continuous process of changes throughout life of an organism. Human growth is an active dynamic process which involves incessant change but, human beings are quite peculiar in this regard as they are born almost immature and spend nearly one third of their life growing, developing and training their abilities to survive. Human beings experience puberty during adolescence which is accompanied by a highly accelerated growth [1]. The study of human growth has been synonymous with measurements. Thus, the majority of traits in growth are quantitative characters. Assessment of growth has been traditionally established from height and weight measurements. The progression of growth follows a pattern that is consistent within individual but involves a wide range of differences with regard to age of onset and duration of specific stages as well as in the intensity of these changes. However, the basic developmental norms are constant for all children belonging to different ethnic groups [2,3].

Although, social class related differences in growth have been documented [4-6], the fact that large variation is seen even within the same community has not received much attention. Differences in dietary intake alone are unlikely to explain between individual variations in adolescent growth as there is hardly any evidence for the relationship between the two during adolescence [7-9].

*Address correspondence to this author at the Department of Anthropology, University of Delhi, Delhi 110007, India; Tel: 011-27667329; Fax: 01127666614; E-mail: satwanti@yahoo.com
Fat distribution pattern is drawing much attention due to its association with various chronic degenerative diseases [10-15]. However, any analysis of fat distribution in diseases must take into account distributional variation with age and sex $[3,16,17]$. Linear measurements changes with age are undoubted. It has also been established that fat distribution changes systematically from infancy through late childhood $[18,19]$. Different studies on the pattern of subcutaneous fat distribution among various populations all over the world reveals that it is related to number of factors which could be genetic, environmental, socio-economic, nutritive, type and level of physical activity [20-22].

India's unique caste system has attracted the attention of human geneticists and anthropologists to examine the intricacies involved in biological and socio-cultural aspects. Most anthropometric traits manifest as continuous graded characteristics which may be produced by the action of either genetic or environmental factors or combination of both. Although, growth is known to be influenced by genetic as well as environmental factors, the latter are of greater importance.

Anthropometry provides the single most portal, universally applicable, non-invasive and inexpensive techniques for assessing the size, proportions and composition of human body. Anthropometry is particularly important during adolescence because it allows the monitoring and evaluation of changes in growth and maturation during this period. Anthropometric variability in Indian populations is remarkable due to the influences of several factors, nutritional and socioeconomic [23-25]. 
Table 1. Basic Data of Adolescent Boys: Punjabi Khatri and Jat Sikhs

\begin{tabular}{|c|c|c|c|c|c|c|c|c|c|c|c|c|c|c|}
\hline \multirow[t]{2}{*}{ Age(yr) } & \multicolumn{2}{|c|}{11} & \multicolumn{2}{|c|}{12} & \multicolumn{2}{|c|}{13} & \multicolumn{2}{|c|}{14} & \multicolumn{2}{|c|}{15} & \multicolumn{2}{|c|}{16} & \multicolumn{2}{|c|}{17} \\
\hline & $\begin{array}{c}\text { Punjabi } \\
\text { Khatri } \\
(n=60)\end{array}$ & $\begin{array}{c}\text { Jat } \\
\text { Sikhs } \\
(\mathbf{n = 2 0})\end{array}$ & $\begin{array}{l}\text { Punjabi } \\
\text { Khatri } \\
(n=61)\end{array}$ & $\begin{array}{c}\text { Jat } \\
\text { Sikhs } \\
(\mathbf{n = 2 0})\end{array}$ & $\begin{array}{c}\text { Pun- } \\
\text { jabi } \\
\text { Khatri } \\
(n=65)\end{array}$ & $\begin{array}{c}\text { Jat } \\
\text { Sikhs } \\
(\mathbf{n = 2 0})\end{array}$ & $\begin{array}{c}\text { Punjabi } \\
\text { Khatri } \\
(n=61)\end{array}$ & $\begin{array}{c}\text { Jat } \\
\text { Sikhs } \\
(\mathbf{n}=\mathbf{2 0})\end{array}$ & $\begin{array}{c}\text { Punjabi } \\
\text { Khatri } \\
(n=53)\end{array}$ & $\begin{array}{c}\text { Jat } \\
\text { Sikhs } \\
(\mathbf{n}=\mathbf{2 0})\end{array}$ & $\begin{array}{c}\text { Punjabi } \\
\text { Khatri } \\
(n=60)\end{array}$ & $\begin{array}{c}\text { Jat } \\
\text { Sikhs } \\
(\mathbf{n = 2 0})\end{array}$ & $\begin{array}{c}\text { Pun- } \\
\text { jabi } \\
\text { Khatri } \\
(n=54)\end{array}$ & $\begin{array}{c}\text { Jat } \\
\text { Sikhs } \\
(\mathbf{n}=20)\end{array}$ \\
\hline $\begin{array}{c}\text { Body weight } \\
(\mathrm{kg}) \text { Mean } \\
\pm \mathrm{SD}\end{array}$ & $\begin{array}{c}34.5 \\
7.9\end{array}$ & $\begin{array}{c}33.0 \\
4.9\end{array}$ & $\begin{array}{c}37.1 \\
7.9\end{array}$ & $\begin{array}{c}40.1 \\
5.3\end{array}$ & $\begin{array}{c}41.9 \\
9.4\end{array}$ & $\begin{array}{c}43.9 \\
7.8\end{array}$ & $\begin{array}{c}45.2 \\
9.3\end{array}$ & $\begin{array}{c}46.0 \\
6.2\end{array}$ & $\begin{array}{l}51.9 \\
10.3\end{array}$ & $\begin{array}{c}52.9 \\
8.1\end{array}$ & $\begin{array}{c}55.4 \\
8.8\end{array}$ & $\begin{array}{c}57.2 \\
7.9\end{array}$ & $\begin{array}{c}56.19 \\
9.92\end{array}$ & $\begin{array}{c}63.5 \\
4.8\end{array}$ \\
\hline $\begin{array}{c}\text { Body height } \\
(\mathrm{cm}) \text { Mean } \\
\pm \mathrm{SD}\end{array}$ & $\begin{array}{c}140.1 \\
7.1\end{array}$ & $\begin{array}{c}141.9 \\
4.4\end{array}$ & $\begin{array}{c}144.9 \\
8.1\end{array}$ & $\begin{array}{c}151.3 \\
5.4\end{array}$ & $\begin{array}{c}151.9 \\
8.1\end{array}$ & $\begin{array}{c}150.2 \\
7.8\end{array}$ & $\begin{array}{c}153.9 \\
22.4\end{array}$ & $\begin{array}{c}157.1 \\
6.4\end{array}$ & $\begin{array}{c}160.1 \\
7.6\end{array}$ & $\begin{array}{c}162.4 \\
4.7\end{array}$ & $\begin{array}{c}167.9 \\
5.8\end{array}$ & $\begin{array}{c}168.2 \\
3.6\end{array}$ & $\begin{array}{c}168.1 \\
1 \\
4.1\end{array}$ & 170. \\
\hline $\operatorname{BMI}\left(\mathrm{kg} / \mathrm{m}^{2}\right)$ & 18.13 & 16.39 & 17.66 & 17.52 & 18.15 & 19.46 & 19.49 & 18.64 & 19.32 & 20.06 & 19.62 & 20.22 & 19.91 & 21.74 \\
\hline GMT & 12.02 & 10.52 & 12.18 & 11.67 & 12.08 & 10.8 & 9.64 & 12.55 & 10.63 & 11.8 & 11.54 & 10.1 & & \\
\hline
\end{tabular}

An attempt has been made in the present study to establish the trend of changes in some linear and adiposity dimensions during adolescence period in an endogamous Punjabi Khatri population and to compare the same with genetically different population-the Jat Sikhs for profile of fatness during same period.

\section{MATERIALS AND METHODOLOGY}

The present study comprises a cross sectional data on four hundred and fourteen adolescent boys studying in schools who volunteered as subjects. The subjects belonged to urban based endogamous Punjabi Khatri and within the population no further distinction with respect to subcaste was made. All the families were residing in Delhi at the time of study. The subjects included adolescents at a yearly interval from age 11 through 17 years. This group was compared with endogamous one hudred and forty Jat Sikhs, one of the most numerous agricultural land owning rural community [26] for profile of fatness. The anthropometric measurements taken on adolescent boys include weight and stature. Skinfold thickness at biceps, triceps, suprailiac and medial calf were taken on Punjabi khatri and Jat Sikh boys. All the measurements were taken according to the techniques described by Weiner and Laurie [27].

To visualize fatness body mass index (BMI) was calculated as weight in $\mathrm{kg}$ divided by stature in meter square, Grand mean thickness (GMT) was computed by dividing sum of all the skinfold thickness by the number of sites and the profile of subcutaneous fat distribution over the body was obtained by arranging the skinfold sites in ascending order of thickness. To study the sensitivity of deposition of subcutaneous fat at different sites, each site was expressed as percent of GMT [17].

\section{RESULTS}

Table 1 shows a gradual increase of weight from 11 to 16 years among the Punjabi Khatri boys, while a marginal increase from 16 to 17 years, the same being true for stature also. A maximum increase corresponding to adolescent spurt in weight is at 14-15 years and in stature it has been seen in age group 15-16 years. The Jat Sikh boys increase gradually with peak increase in stature at 13-14 years of age followed by peak increase in weight at $14-15$ years. Though there is an increase in BMI among the boys, no consistent pattern is observed with adolescent Punjabi khatri having more BMI than Jat Sikhs. Among the Punjabi khatri adolescent boys there is a fluctuation in fat content when calculated from GMT with maximum fat content at 12 years and in subsequent years it declines though pattern is inconsistent. As for Jat Sikh boys, maximum GMT is at 14 years and then fat decreases during the period.

In order to study the pattern of subcutaneous fat distribution among adolescent boys both Punjabi khatri and Jat Sikhs (Table 2, Fig. 1) biceps, triceps, suprailiac and medial calf are selected. The profile of the subcutaneous fat was studied by arranging skinfold site in ascending order of their thickness for all the age groups. Biceps remains the site of minimum fat in all the age groups in both Punjabi khatri and Jat Sikh adolescent boys. The pattern is same in all the age groups in Punjabi khatri boys affirming the phenomenon of redistribution of fat away from extremity towards the trunk. As far as Jat Sikh adolescent boys are concerned there is an intersite shift at 17 years from suprailiac to medial calf deviating from the usual away from extremity towards the trunk.

As can be clearly seen from Fig. (2) suprailiac is the most sensitive site followed by medial calf in both adolescent Punjabi khatri and Jat Sikh boys.

\section{DISCUSSION}

Small but significant relationship have been observed between age and various body measurements both in Punjabi khatri and Jat Sikh pointing towards age dependent growing period. To understand minutely every detail of the change that takes place around this critical period, each age group has been dealt separately. Thus, there are seven age groups each of Punjabi khatri and Jat Sikh adolescent boys from 11 through 17 years.

Both the groups' Punjabi khatri and Jat Sikh adolescent boys have comparable ages, point towards weight spurt in 15 years. However spurt in stature is earlier in Jat Sikhs at 14 years while in Punjabi khatri it is later that is at 16 years. 
Table 2. Skinfold Thickness at Different Sites of Adolescent Boys Punjabi Khatri and Jat Sikhs

\begin{tabular}{|c|c|c|c|c|c|c|c|c|c|c|c|c|c|c|}
\hline \multirow[t]{2}{*}{$\operatorname{Age}(y r)$} & \multicolumn{2}{|c|}{11} & \multicolumn{2}{|c|}{12} & \multicolumn{2}{|c|}{13} & \multicolumn{2}{|c|}{14} & \multicolumn{2}{|c|}{15} & \multicolumn{2}{|c|}{16} & \multicolumn{2}{|c|}{17} \\
\hline & $\begin{array}{l}\text { Punjabi } \\
\text { Khatri }\end{array}$ & $\begin{array}{c}\text { Jat } \\
\text { Sikhs }\end{array}$ & $\begin{array}{l}\text { Punjabi } \\
\text { Khatri }\end{array}$ & $\begin{array}{c}\text { Jat } \\
\text { Sikhs }\end{array}$ & $\begin{array}{l}\text { Punjabi } \\
\text { Khatri }\end{array}$ & $\begin{array}{c}\text { Jat } \\
\text { Sikhs }\end{array}$ & $\begin{array}{l}\text { Punjabi } \\
\text { Khatri }\end{array}$ & $\begin{array}{c}\text { Jat } \\
\text { Sikhs }\end{array}$ & $\begin{array}{l}\text { Punjabi } \\
\text { Khatri }\end{array}$ & $\begin{array}{c}\text { Jat } \\
\text { Sikhs }\end{array}$ & $\begin{array}{l}\text { Punjabi } \\
\text { Khatri }\end{array}$ & $\begin{array}{c}\text { Jat } \\
\text { Sikhs }\end{array}$ & $\begin{array}{l}\text { Punjabi } \\
\text { Khatri }\end{array}$ & $\begin{array}{r}\text { Jat } \\
\text { Sikhs }\end{array}$ \\
\hline Biceps Mean & 7.35 & 8.9 & 7.22 & 7.3 & 7.04 & 7.6 & 5.58 & 7.3 & 5.77 & 6.7 & 6.02 & 5.9 & 4.33 & 8.4 \\
\hline$\pm \mathrm{SD}$ & 3.39 & 2.7 & 2.69 & 2.6 & 3.21 & 4.9 & 2.87 & 3.7 & 2.92 & 2.7 & 1.71 & 2.9 & 2.22 & 2.1 \\
\hline Triceps Mean & 12.02 & 10.4 & 11.71 & 11.1 & 11.47 & 9.4 & 9.05 & 10.6 & 9.29 & 10.1 & 9.73 & 9.5 & 7.51 & 12.6 \\
\hline$\pm \mathrm{SD}$ & 3.85 & 2.9 & 4.99 & 3.7 & 4.11 & 3.6 & 4.8 & 4.4 & 4.68 & 3.9 & 4.17 & 4.7 & 4.57 & 3.4 \\
\hline Suprailiac Mean & 15.52 & 9.7 & 15.44 & 11.6 & 15.38 & 11.8 & 12.11 & 14.8 & 15.55 & 15.2 & 18.06 & 12.5 & 14.85 & 15.1 \\
\hline$\pm \mathrm{SD}$ & 7.54 & 6.1 & 5.89 & 4.3 & 6.53 & 8.9 & 7.21 & 9.8 & 7.33 & 4.3 & 9.77 & 7.0 & 4.14 & 4.9 \\
\hline Medial calf Mean & 13.19 & 13.1 & 14.34 & 16.7 & 14.44 & 14.4 & 11.84 & 17.5 & 11.92 & 15.2 & 12.37 & 12.5 & 9.35 & 14.7 \\
\hline$\pm \mathrm{SD}$ & 6.9 & 5.9 & 6.43 & 4.1 & 6.92 & 4.6 & 7.2 & 7.2 & 6.82 & 4.8 & 8.09 & 7.0 & 7.38 & 2.3 \\
\hline
\end{tabular}
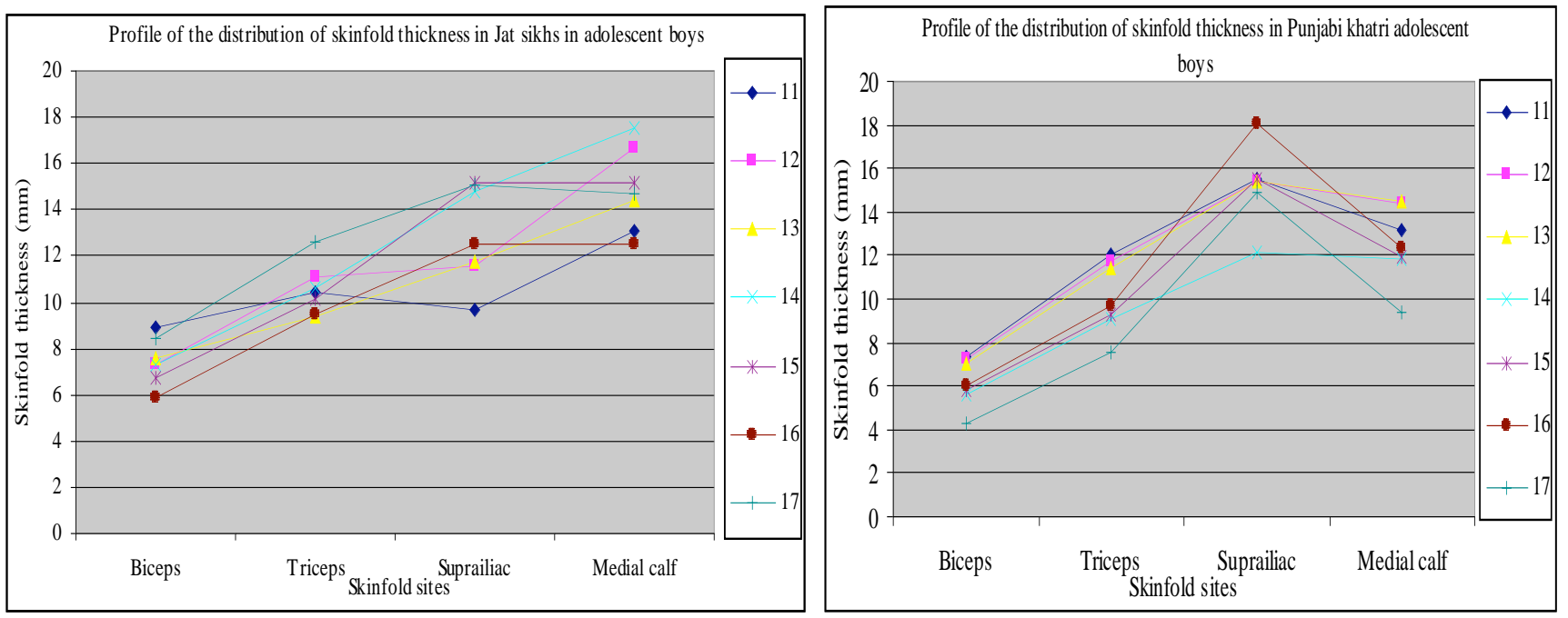

Fig. (1). Profile of distribution of skinfold of skinfold thickness in Jat Sikh and Punjabi khatri adolescent boys.
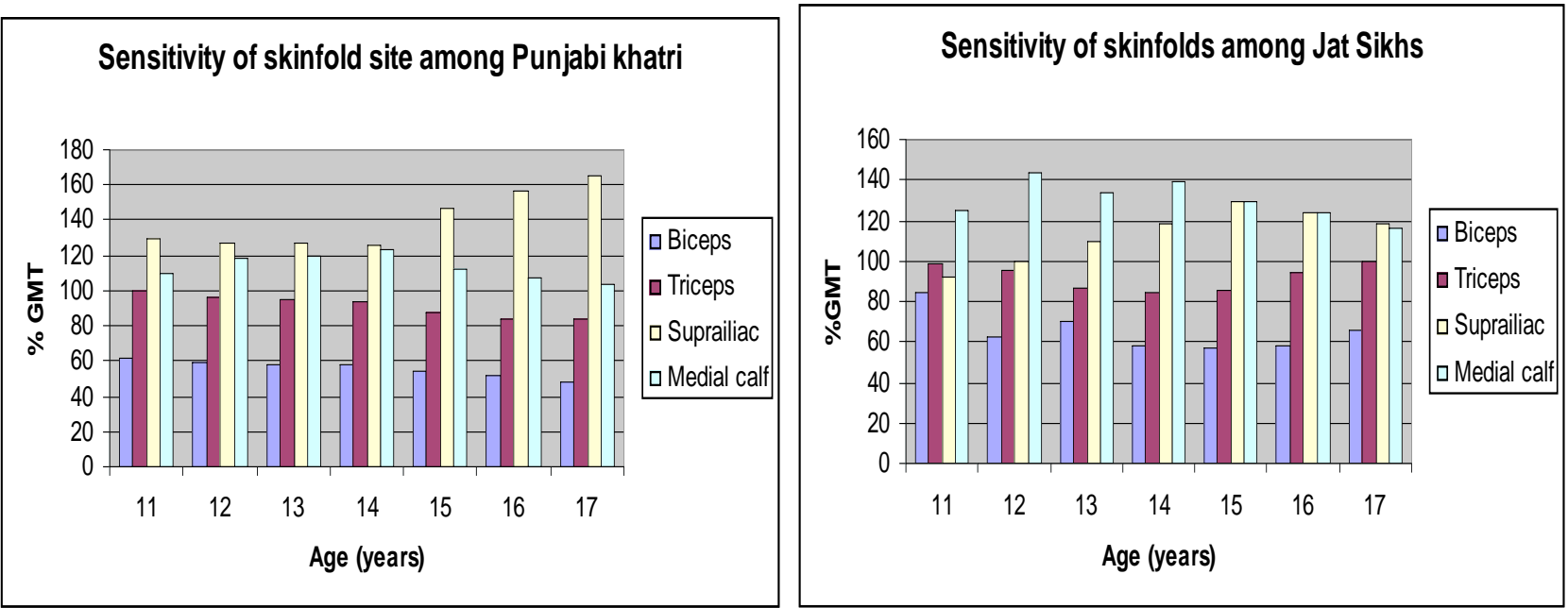

Fig. (2). Sensitivity of different skinfold sites towards accumulation of body fat in Jat Sikh and Punjabi khatri adolescent boys. 
This leads to inference that Jat Sikhs boys have maturity earlier than Punjabi khatri as far as stature is concerned.

Although, the variables in both the groups' Punjabi khatri and Jat Sikh adolescent boys showed an increase with age, the rate of increase and age at which maximum increase corresponding to adolescence spurt occurred varied from variable to variable. This may be attributed to the fact that all body parts of the body do not grow at the same rate. Some body part or dimensions increase more than others during adolescent period and some exhibit spurt earlier than others [28]. The adolescent spurt is a constant phenomenon and occurs in all children, though it varies in duration from one child to another and also from one variable to another.

It has been emphasized that individual growth standards for each endogamous population are required because of genetic determinants of growth pattern [29]. The period of growth of children unfolds a spectrum of changes in size, shape, proportion and maturity status thereby indicating a dynamic state of child [24].

Among the Punjabi khatri adolescent boys there is a fluctuation in fat content when calculated from GMT with maximum fat content at 12 years and in subsequent years it declines though pattern is inconsistent. Theoretically, any change in the GMT would be accompanied by change in thickness of the skinfold at individual site, but the change thus occurring is not uniform at all sites as there is variation in the deposition of fat at different sites. As for Jat Sikh boys, maximum GMT is at 14 years and then fat decreases during the period coinciding with faster growth rate which could be attributed to increased need owing to faster growth rate. The profile of the pattern of subcutaneous skinfold thickness is not the same in both Punjabi khatri and Jat Sikh adolescent boys. GMT does not follow a uniform pattern and even the site of fat deposition also varies with the fluctuation of fat. There is no similarity in different age groups as far as pattern is concerned; this inference is not very real as few sites of skinfold thickness are taken in the present study. Suprailiac site followed by medial calf is found to be sensitive, an indirect evidence of subcutaneous fat deposition shift towards trunkal region. Significant inverse relationships were found for all measures of body size and composition and all physical activity indices [30].

In the present study there is fluctuation in GMT in both the groups while a continuous increase in weight is observed which means that fat increase is used by body build and uses the fat reservoir for extra energy required at adolescence, an important phase for growth. An intriguing feature observed is that minimum GMT in Punjabi khatri and maximum in Jat Sikh is found to be at 17 years.

There is a tendency towards an increase in BMI among the boys though adolescent Punjabi khatri have more BMI than Jat Sikhs and no consistent pattern is observed. Maximum increase in BMI is noticed in late adolescent period at 15-16 years in Punjabi khatri but in Jat Sikh obvious decrease is observed in 14-15 years. BMI has its limitation as such that is why percentiles are used, but among growing children it has significant limitation as differential rate of growth prevails.

Rural and low socio-economic statuses Indians have some of the lowest mean BMI and greatest proportions of the population with BMI below $16 \mathrm{~kg} / \mathrm{m}^{2}$ [31]. The present study reflects that BMI has its limitation as an index of obesity and it is clear that BMI is mirror image of not only fat but muscles and bones too. To interpret BMI in terms of body composition more specifically it is necessary to take into account sex, age and ethnicity.

Although the genetic explanation for obesity is generally acceptable, the recent trends in overweight and obesity suggest that other factors may be equally significant. Recent research has therefore, focused on the role of environmental factors, including socioeconomic status. The studies have generally reported a significant relationship between socioeconomic status and overweight or obesity [32]. Remarkable variation in adiposity among different populations suggests that social, economic and environmental factors are important influences, although it may be true that genetic differences across populations also play a role [33]. Punjabi Khatri were urban based and belong to high socioeconomic group whereas the Jat Sikhs were mostly agricultural land owning rural community. The socioeconomic differences among them influences their body composition and fat distribution pattern as observed. Punjabi Khatri boys had higher grand mean skinfold thickness in most of the age groups showing more subcutaneous fat deposition than the Jat Sikhs boys though they were taller and heavier.

Among the Punjabi Khatri boys maximum skinfold thickness site was observed in suprailiac whereas among the Jat Sikhs boys, it was found in medial calf skinfold thickness site in most of the age groups. It showed that Jat Sikhs boys had the maximum subcutaneous fat deposition in extremities but Punjabi Khatri boys had more subcutaneous fat deposition in trunkal region, which is of greater health significance. City residents have different life-styles than rural dwellers, and these differing living habits establish characteristic patterns of food demands and time allocation. Urban areas over the world are more advanced in obesity than the rural ones [34]. The United States Center for Disease Control [35] also state that the growing obesity rates are an indication of a growing long-term imbalance between an individual's energy intake from food and drink and energy use in basal metabolism, work and leisure, and seem to have little to do with the gene pool of the population, which is fixed.

\section{CONCLUSION}

The present study comprises of cross sectional data on Punjabi Khatri and Jat Sikh adolescent boys at a yearly interval from age 11 through 17 years. A gradual increase of weight from 11 to 16 years and a marginal increase from 16 to 17 years among the Punjabi Khatri boys and peak increase in weight at 14-15 year in Jat sikh boys is noticed. The Jat Sikh boys increase gradually with peak increase in stature at 13-14 years and in Punjabi khatri gradual increase of weight from 11 to 16 years and a marginal increase from 16 to 17 years is observed. Adolescent Punjabi khatri adolescents have more BMI than Jat Sikhs. The pattern is same in all the age groups in Punjabi khatri boys affirming the phenomenon of redistribution of fat away from extremity towards the trunk. As far as Jat Sikh adolescent boys are concerned there is an intersite shift at 17 years from suprailiac to medial calf deviating from the usual away from extremity towards the trunk. Suprailiac is the most sensitive site followed by medial calf in both adolescent Punjabi khatri and Jat Sikh boys. 


\section{ACKNOWLEDGEMENT}

Our sincere gratitude to Professor I.P. Singh for his unconditional and invaluable guidance all through. The financial assistance offered by Indian Council of Medical Research is gratefully acknowledged. The authors are thankful for cooperation extended by the subjects during data collection.

\section{CONFLICT OF INTEREST}

None declared.

\section{REFERENCES}

[1] McCance RA, Widdowson EM. Glimpse of comparative growth and development. In: Falkner F, Tanner JM. (Eds). Human Growth 1. Principles and Prenatal Growth. Plenum Press. London 1978. pp. 145-66.

[2] Valadian I, Ponter D. Physical growth and Development: From conception to maturity. A Programmed Text. $1^{\text {st }}$ ed: Little Brown and Company. Boston 1977.

[3] Sinha R, Kapoor S. Fat patterning among Indian adolescent boys and girls. Ind J Phys Anthropol Human Gen 2005; 24: 135-41.

[4] Banik NPP. 1982. Semi Io. ngitudinal growth evaluation of children from birth to. 14 year in different socio. economic groups. Ind J Ped 1982; 19: 353-9.

[5] Gultekin T, Hauspie R, Sussane C, Gulec E. Growth of children living in the outskirts of Ankara: Impact of low socio-economic status. Ann Human Biol 2006; 33: 43-54.

[6] Lopez-Blanc M. Growth as a mirror of conditions of a developing Society: The case of Venezuela. In: Hauspie R, Lingren G, Falkne RF, (Eds.). Essays on auxology. Welwyn Garden City, UK: Castlmead Publications 1995; pp. 312-21.

[7] Durnin JVGA, Lonergan ME, Good J, Ewan A. A gross sectional nutritional and anthropometpic study with an interval of 7 yrs on 611 young adolescent school children. British J Nut 1974; 32: 16979

[8] Hacket AF. A two year Longitudinal study of dietary intake in relation to. the growth of 405 English children initially aged 11-12 years. Ann Human Biol 1984; 11: 545-53.

[9] Hauspie RC, Vercautern M, Suzzane C. Secular changes in growth. Hormone Res 1996; 45: 8-17.

[10] Lapidus L, Bengtsson C, Larrson B, Pennert K, Rybo E, Sjo“strom L. Distribution of adipose tissue and risk of cardiovascular disease and death: A 12-y follow up of participants in the population study of women in Gothenberg, Sweden. British Med J 1984; 289: 125760.

[11] Larsson N. Fat distribution and risk for death, myocardial infarction and stroke. In: Bouchard C, Johnston FE, (Eds.), Fat Distribution during Growth and Later Health Outcome. Alan R. Liss, New York 1988; pp. 193-201.

[12] Bouchard C, Despres JP, Tremblay A. Exercise and obesity. Obes Res 1993; 1: 133-47.

[13] Ducimetiere P, Richard J, Cambien F. The pattern of subcutaneous fat distribution in middle aged man and the risk of coronary heart disease: the Paris prospective study. Int J Obes 1986; 10: 229-40.

[14] Kapoor S, Tungdim MGD, Kapoor AK. Temporal recovery in morphological and physiological indicators with $\mathrm{TB}$ treatment among tribal population of Manipur, North East India. Anthropol Int J Sci Man 2005; 1: 2

[15] Kissebah AH, Peiris A, Evans DJ. Mechanisms associating body fat distribution to glucose intolerance and diabetes mellitus. In: Bouchard C, Johnston FE, (Eds.), Fat Distribution During Growth and Later Health Outcomes. Alan R. Liss, New York 1988; pp. 203-20.

[16] Joyce KP, Kapoor S. Pattern of subcutaneous fat distribution, its variation with age among young Rajput females of Pauri Garhwal. Indian J Human Ecol1996; 7: 45-9.

[17] Satwanti, Singh IP, Bharadwaj H. Fat distribution in lean and obese young Indian women: a densitometric and anthropometric evaluation. Am J Physical Anthropol 1980; 53: 611-6.

[18] Bailey SM, Gershoff SN, Mc Gandy RB, Nadosita A, Tantiwongse P. Subcutaneous fat remodeling in S. E. Asian infants and children. Ame J Phys Anthropol 1985; 68: 123-30.

[19] Baumgartner RN, Roche AF Tracing of fat pattern indices in childhood: the Melbourne growth study. Human Biol 1988; 60: 549-67.

[20] Garn SM. Fat patterning and fat intercorrelation in adult males. Human Biol 1954; 26: 59-69.

[21] Borkan GA, Norris AH. Fat redistribution and the changing body dimensions of the adult male. Human Biol 1977; 49: 495-513.

[22] Bhalla R, Kapoor AK, Satwanti, Singh I. The distribution of subcutaneous fat with reference level of physical activity in adult females. Z Morph Anthrop 1985; 74: 191-7.

[23] Eveleth PB. Population differences in growth. In: Falkner F, Tanner JM, (Eds.). Human Growth: A Comprehensive Treatise. New York, NY: Plenum Press 1986; pp 221-39.

[24] Eveleth PB, Tanner JM. World-wide Variation in Human Growth Cambridge, UK: Cambridge University Press. 1990.

[25] Harrison GA, Schmitt LH. Variability in stature growth. Ann Human Biol 1989; 16: 45-51.

[26] Kapoor S, Patra PK, Sandhu S, Kapoor AK. Fatness and its distribution pattern among Jat Sikhs. J Ind Anth Soc 1998; 33: 223-8.

[27] Weiner JS, Lowrie JA. Human Biology, A guide to field methods. IBP Handbook no 9, Oxford Blackwell Sci. Publication 1981

[28] Tanner JM. Growth at adolescence. $2^{\text {nd }}$ edition. Blackwell Scientific Publication, Oxford. 1962.

[29] Lowrey GH. Growth and development of children. Year Book Medical Publishers, Inc., Chicago. 1986

[30] Lohman TG, Ring K, Schmitz FH, et al. Associations of Body Size and Composition with Physical Activity in Adolescent Girls. Med Sci Sports Exerc 2006; 38: 1175-81.

[31] Arya RD, Duggirala R, Comuzzie AG, et al. Heritability of anthropometric phenotypes in caste populations of Visakhapatnam, India. Human Biol 2002; 74: 325-44.

[32] Abdulai A. Socio-economic characteristics and obesity in underdeveloped economies: does income really matter? App Eco 2010; 42: 157-69

[33] Bray GA, Bouchard C, James WPT. Hand book of obesity. New York; Marcel Dekker 1998.

[34] Popkin BM. Urbanization, lifestyle changes and the nutrition transition. World Dev1999; 27: 1905-16.

[35] US Department of Health and Human Services, Center for Disease Control and Prevention (2000). Overweight and obesity factors contributing to obesity: Biological, behavioral and environmental factors associated with overweight and obesity. www.cdc. gov/nccdphp/dnpa/obesity/state_programs/index.htm [Accessed July 2005]. 